\title{
Improving Methods of State Management of Socio- Economic Processes in the Conditions of Digitalization of the Economy
}

\author{
Piunko L.E. , Tolkacheva E.V. \\ Far-East Institute of management, branch of the Russian Presidential Academy of National Economy and Public \\ Administration (hereinafter RANEPA), Department of mathematical methods and information technologies, Khabarovsk \\ 680000, Russia \\ *Corresponding author. Email: lusiena_03@mail.ru
}

\begin{abstract}
The relevance of the study of the problem of state management of socio-economic processes is due to the active digitalization of all spheres of public life. In these conditions, the business community has realized the need to accelerate the digitalization of production and technological processes in order to achieve competitive positions in the emerging global digital space. The population is set the task of mastering new digital competencies in the professional and household sphere of life. State institutions take into account the need to create conditions for flexible and effective digitalization of socio-economic processes. Thus, it becomes an important task to develop or select the best methods and tools for public management of socio-economic processes. As well as an analysis of its results in the medium term.
\end{abstract}

Keywords: regulation of socio-economic processes, digital transformation, digital economy, "end-to-end"

digital technologies, methods of public administration, neural networks, forecasting methods

\section{INTRODUCTION}

All socio-economic processes in the regions are subject to managerial influence by state Executive bodies. The formed regional technologies for managing socioeconomic processes are being transformed under the influence of digitalization of the world economy as an external economic and political challenge.

The methods of state management of socio-economic processes used in the conditions of digitalization of the economy: production, labor, organizational, information and technological, need scientific understanding and analysis. Given the volume of data that characterize the system of state management of socio-economic processes, it is no less important to search for new tools for its analysis [1], [2].

\subsection{The essence of public administration in the context of the digital economy}

Targeted impact on natural and social processes to ensure the desired changes in the state of the economy and social sphere - this is the essence of public administration, including that reflected in the dynamics of changes of indicators: the volume of products sold (including for export) and the rate of updates, level of profits and solvency, capacity utilization and other resources, gross domestic product (GDP), highlighting the share of labor (and investment) income of the population, GDP per capita and per worker, wages, consumer price index (inflation), minimum wage (average per capita), the population with incomes below the subsistence minimum, unemployment rate, etc. based On the analysis and evaluation of indicators of the actual state of the economy and the sociolabour sphere and predicts the possible changes in their scientific, technological and social factors in the strategic plan and tactical, depending on the prevailing trends in the change in market conditions, due to the really occurring socio-economic processes. There is a complex relationship dimension of digitalization of economic, social and qualitative assessment of socio-economic processes in the context of the digitalization of the economy.

The methodology for analyzing the system of state management of socio-economic processes in the context of digitalization of the economy is currently described by scientists only in General terms and is not sufficiently systematized. The lack of these studies can have a negative impact on the measures of management influence on socio-economic processes developed in the regions, when the targets are described vaguely, and methods for evaluating and analyzing the results achieved, including comparing the values of indicators, are not provided. 


\subsubsection{Researchers ' approaches to defining the functions of public administration in the context of the digital economy}

Researchers define the functions of state management of economic and social processes, based on the position that economic and social processes, reflecting the dynamics of the economy, themselves at the same time perform the role of not only objects of managerial influence, but also means of their implementation, while highlighting the following functions: analysis and evaluation, forecasting development trends, strategic planning for the development of economic and social processes, organization of economic regulation processes, implementation of project and regulatory decisions [3].

Domestic researchers do not pay enough attention to regional aspects of the development of the digital economy in Russia, and in particular, on the territory of the far Eastern region (Zubarev A. E., Zhadan I. E., Sudarushkina I. V., Stefanova N. A., Chernova V. Yu., Shvab K. [7], [8], [9], [10], [11], [12]). At the same time, regional digital economy projects are largely the main mechanism for the successful implementation of the new national program "Digital economy of the Russian Federation".

\subsubsection{Indicators that characterize the state management of socio-economic processes}

Today in Russia, the main method of managing economic development is program-target management. At the same time, program-target management of the region (goalresources (specified activities)- result) is one of the most effective methods of regulating the development of the regional economy, allowing to concentrate resources on achieving specific socially significant goals. Target programs are complexes of research, development, organizational, economic, and other measures that are linked by resources, performers, and terms of implementation that ensure effective solutions to specific tasks in the field of state Federal construction, scientific and technical, economic, investment, socio-demographic, foreign economic, cultural, environmental, and regional development of the Russian Federation [4].

Public management of socio-economic processes in the context of digitalization of the economy can be characterized by a number of production, labor, organizational, information and technological indicators:

- the number of employees of the organization who have completed advanced training courses in the field of ICT (information and communication technologies) application;

- the number of people (by age group and gender) who have mastered new professions in the digital economy, indicating the clustering of new professions (for example, BigData operator, online lawyer, online it marketer); - number of new domestic software products developed; - share of demand for domestic software in the total share;
- number of enterprises with the introduction of new domestic software;

- the number of domestic server hardware produced;

- the number of working terminals replaced with domestic analogues;

- number of organizations working with BigData;

- the number of organizations that use artificial intelligence in their work;

- the number of people using conversational chatbots in their work / life;

- number of used / developed domestic expert systems;

- number of employees using expert systems / artificial intelligence, etc. (based on open data analysis [13], [14], [15], [16], [17], [18]).

At the same time, the main regularities that determine the methods and forms of state management of socioeconomic processes in the conditions of digitalization of the economy have not been sufficiently identified. State management of socio-economic processes in the context of digitalization of the economy has a complex structure. Its analysis involves processing a large amount of data describing production, labor, organizational, information and technological processes. Methods of state management of socio-economic processes in the conditions of digitalization of the economy also integrate the entire volume of administrative, socio-psychological and economic methods used for management in the "predigital" period.

Thus, to solve the problems of clustering and classification, it is advisable to use neural network analysis, which allows you to correlate the indicators indicated in regional programs for the development of the digital economy with the criteria for positive dynamics of socio-economic processes. For example, how can the indicator "the share of paramedic and midwifery stations of medical organizations of the state and municipal health systems connected to the Internet" be correlated with the growth of the working capacity of the population of the region.

\subsection{Mechanisms for modeling socio-economic processes using neural network technologies}

Modeling patterns between the processes of digitalization of the economy and the transformation of economic processes based on neural networks involves the development of an information model that includes the input values of indicators designated in the regional projects "Information infrastructure", "Information security", "Digital public administration", "Digital technologies", as well as indicators of socio-economic development of the region ([6], [17], [18]). At the output, we get solutions that characterize the possibility of positive dynamics of socio-economic processes in the region due to the development of the digital economy. When setting such a task, the exact type of connections between the inputs and outputs of the information system is unknown. In the course of modeling this neural network, 
the problem of choosing the type of networks is also solved: a linear network, a probabilistic network, a network based on radial basis functions, a multilayer perceptron or a combination of them. Since we don't know the output data, unmanaged training will be used to solve this problem, which allows us to find clusters in the input data.

The lack of information on the use of new developments in the it sphere, the need for domestic developments creates distorted research directions for state management of digitalization processes.

This determines the need to develop tools for their identification and assessment.

Thus, the use of neural network analysis will allow us to systematize the existing indicators of the development of the digital economy and socio-economic development of the region. In turn, the data obtained can be used primarily for the development of administrative and administrative measures.

\subsection{General features of the study}

The rest of the article is organized as follows. Section 2 introduces preliminary results based on a preliminary model of patterns of state management of digital transformation processes in socio-economic systems.

Based on the obtained model, the authors try to determine the principles of effective implementation of changes in socio-economic systems in the context of digitalization of the economy. Section 2 concludes the material of this article and presents the direction of future fundamental research.

\section{MAIN CONCLUSIONS}

\subsection{Approaches to the formation of a model of public administration of socio-economic processes in the digital economy}

The results of the research, using neural networks, can be a reliable basis for the formation of state social and economic policy at all levels of government, in the preparation and implementation of Federal and regional programs for the reform of social sectors.

The area of analysis and forecasting of state management of socio-economic processes in the context of digitalization of the economy is currently insufficiently systematized by scientists, only in General outlines they describe these objects. The lack of these studies is felt in the Federal projects for the development of the digital economy and their regional subprograms: where targets are described vaguely, and methods for evaluating and analyzing the results achieved, including comparing the values of indicators are not provided

Using information technologies and computer systems as tools for analyzing socio-economic processes, you can:
- conduct a comprehensive assessment of the current processes of digitalization of the socio-economic sphere of the regions;

- using neural network analysis, identify and evaluate stochastic processes of integration of the digital economy into the socio-economic environment of regions;

- to find new methodological solutions for state management of socio-economic systems in the conditions of digitalization of the economy.

The authors, in the course of their research, determined the following:

1. Intelligent information technologies and computer systems can be used as tools for objective research of methods of state management of socio-economic processes and its results.

2. Within the subject area of macroeconomics, issues of optimizing socio-economic development are studied from the point of view of their stability, stability and economic growth, and in modern conditions, the processes of digitalization are taken into account.

In addition, the scientific significance of the study is to identify the possibilities of using neural network analysis to identify patterns of state management of socioeconomic processes.

The instrumental approaches proposed in the study to the analysis of state management of socio-economic processes in the region allow us to find out the role of regional projects of digitalization of the economy in the dynamics of socio-economic indicators of the region. Due to the fact that classical statistical and econometric methods of analyzing such complex patterns can give a distorted result, and require a long time to evaluate the factors that need to be included in the model, as well as to assess the error of the model itself, neural networks are seen as a more effective tool.

Also, the authors determined the following in the course of their research:

1. Public management of socio-economic processes in the context of the digital economy " is interdisciplinary.

2. Within the subject area of macroeconomics-issues of socio-economic development are studied from the perspective of their stability, stability and economic growth, and in modern conditions, taking into account the processes of digitalization.

3. Within the subject area of information technologies and computing systems - the impact of end-to-end digital technologies on the patterns of state management of socioeconomic systems.

4. In modern conditions, an important task is the application of Data Mining methods in the study of patterns of state management of socio-economic processes.

\subsection{Significance of research on socio- economic processes based on neural networks}

The data obtained in the course of the study have both general theoretical and applied significance. They will allow us to systematize existing ideas about managing 
[4] Official site "Infopedia-site for deepening theoretical and practical knowledge" [Electronic resource] / [access Mode] : https://infopedia.su/16x32dd.html (accessed: 23.03.2020)

[5] Ashmarov I. A. Economic processes and structures and their classification [Electronic resource] / [access Mode]: https://cyberleninka.ru/article/n/ekonomicheskieprotsessy-i-struktury-i-ih-klassifikatsiya/viewer

[6] Decree of the President of the Russian Federation of 07.05.2018 №204 "On national goals and strategic objectives of the development of the Russian Federation for the period up to 2024" [Electronic resource] / access Mode: http://www.kremlin.ru/acts/bank/43027/page/2.

[7] Zubarev A. E. Digital economy as a form of manifestation of regularities in the development of the new economy. Vestnik TOGU. 2017. No. 4 (47). Pp. $177-184$

[8] Zhadan I. E. Social risks in the digital economy / / Humanitarian scientific journal. 2018. \#11. Pp. 20-26.

This work was supported by Far-East Institute of management, branch of the Russian Presidential Academy of National Economy and Public Administration (hereinafter RANEPA), Department of mathematical methods and information technologies, Khabarovsk 680000 , Russia.

\section{REFERENCES}

[1] Vorobyov A. A., kotenkova S. N. State and regional management of socio-economic processes: educational and methodological guide / A. A. Vorobyov, S. N. kotenkova. - Kazan, 2017. - 114 p. S. 37-43; P. 48-51

[2] Pastukhov V. B. the Regulation of social and economic processes // Izvestiya tulgu. Economic and legal Sciences. 2013. \#3-1. URL: https:/cyberleninka.ru/article/n/regulirovanie-sotsialnoekonomicheskih-protsessov (date accessed: 23.03.2020)

[3] Khachak R. B. Problems of methodology of analysis of economic processes / / Izvestiya RSPU im. A. I. Herzen. 2008. No. 73-1. URL: https://cyberleninka.ru/article/n/problemy-metodologiianaliza-ekonomicheskih-protsessov (date accessed: 23.03.2020).
[9] Sudarushkina I. V., Stefanova N. A. Digital economy / / ANI: Economics and management. 2017. No. 1 (18). Pp. 182-184.

[10] Chernova V. Yu. Russian consumer in the digital economy / / Discussion. 2019. No. 2 (93). Pp. $38-41$.

[11] Shvab K. the Fourth industrial revolution / K. Shvab - "Eksmo", 2016 - (Top Business Awards) [Electronic resource] / access Mode: http://ncrao.rsvpu.ru/sites/default/files/library/k. shvab _chetvertaya_promyshlennaya_revolyuciya_2016.pdf

[12] Information society: main characteristics of the subjects of the Russian Federation: statistical collection / M. A. Sabelnikova, G. I. Abdrakhmanova, L. M. Gokhberg, O. Yu. Dudorova et al.; Rosstat; national Statistical service. research. Higher school of Economics. Moscow: HIGHER school of Economics, 2018. - $216 \mathrm{p}$

[13] The official website of "Levada-center". [Electronic resource] / access Mode: https://www.levada.ru/

[14] The official website of "Levada-center". [Electronic resource] / access Mode: 
https://www.levada.ru/2019/11/11/2-rossiyanpolnostyu-otkazalis-ot-nalichnyh/ access date: 11.11.2019.

[15] The official website of "Levada-center". [Electronic resource] / access Mode: https://www.levada.ru/2019/04/15/otsenka-biznesomvvedeniya-markirovki-tovarov-v-rossii/

[16] The official website of "Levada-center". [Electronic resource] / access Mode: https://www.levada.ru/2018/11/13/polzovanieinternetom-2/ access date: 11.11.2019.

[17] Digital economy-national projects-Khabarovsk territory. [Electronic resource] / access Mode: https://www.khabkrai.ru/khabarovsk-krai/Proekty/1754 69. access date: 08.09.2019.

[18] Official portal "Ministry of digital development, communications and mass communications of the Russian Federation" [Electronic resource] / access Mode: https://digital.gov.ru/ru/pages/ statistika-otrasli 